\title{
PEMANFAAT AN SISTEM INFORMASI DALAM PENGELOLAAN SUMBANGAN SUKARELAWAN SISWA DI SMA NEGERI 20 MEDAN
}

\author{
Sri Haryati ${ }^{1}$ \\ Khairul $^{2}$ \\ Sri Nadriati ${ }^{3}$
}

\begin{abstract}
The purpose of this study is to analyze the weaknesses in the current system is the manual system at SMA Negeri 20 Medan and propose and design the development and addition of technology on the new system. This is done in order to support the operational work process in SMA Negeri 20 Medan, especially the financial section. Volunteer Contribution Management Information System This student consists of several modules, namely login module, data entry module, transaction module, and report generation module. The student volunteer donation information processing system is designed using MySQL for database design, Java for application program design, and iReport to support report generation on the program. The advantage of this Information System is that it can display multiple reports. Existing reports can be used in decision-making by management, as well as support in school operational processes.
\end{abstract}

Keywords: Information System, Contribution of student volunteers, MySQL, JAVA

\begin{abstract}
ABSTRAK
Tujuan dari penelitian ini adalah untuk menganalisis kelemahan pada sistem yang sedang berjalan saat ini yaitu sistem manual pada SMA Negeri 20 Medan dan mengusulkan dan merancang pengembangan dan penambahan teknologi pada sistem baru. Hal ini dilakukan agar dapat mendukung proses kerja operasional di SMA Negeri 20 Medan, khususnya bagian keuangan. Sistem Informasi Pengelolaan Sumbangan Sukarelawan Siswa ini terdiri dari beberapa modul yaitu modul login, modul entri data, modul transaksi, serta modul pembuatan laporan. Sistem informasi pengolahan sumbangan sukarelawan siswa dirancang dengan menggunakan MySQL untuk perancangan basis data, Java untuk perancangan program aplikasi, serta iReport untuk mendukung pembuatan laporan pada program. Keunggulan dari Sistem Informasi ini adalah dapat menampilkan beberapa laporan. Laporan yang ada tersebut dapat digunakan dalam pengambilan keputusan oleh manajemen, serta menunjang dalam proses operasional Sekolah.
\end{abstract}

Kata kunci : Sistem Informasi, Sumbangan Sukarelawan Siswa, MySQL, JAVA

\footnotetext{
${ }^{1}$ Dosen Prodi Sistem Komputer Universitas Pembangunan Panca Budi Medan

2. Dosen Prodi Sistem Komputer Universitas Pembangunan Panca Budi Medan

3. Dosen Prodi Sistem Komputer Universitas Pembangunan Panca Budi Medan
} 


\section{PENDAHULUAN}

Perkembangan IPTEK (IImu Pengetahuan dan Teknologi) cenderung dikaitkan dengan komputer yang sangat penting penggunaannya dan bertujuan untuk mempermudah suatu pekerjaan manusia. Kehadiran teknologi komputer dengan kekuatan prosesnya telah memungkinkan pengembangan sistem informasi manajemen berbasis komputer. Dengan memanfaatkan teknologi komputer, didapat manfaat berupa kemudahan menyimpan, mengorganisasikan dan melakukan pengambilan (retrieval) terhadap berbagai data.

Pentingnya komputer dalam suatu sistem informasi sangat mendukung khususnya buat SMA Negeri 20 Medan dalam pengolahan dan menampilkan data (output). SMA Negeri 20 Medan salah satu sekolah yang belum memiliki sistem informasi pengolahan data uang sumbangan sukarelawan siswa, pembayaran uang sumbangan sukarelawan masih dilakukan secara manual, sehingga kurang mampu dalam memberikan informasi secara cepat dan tepat. Hal ini disebabkan karena banyaknya siswa dari 3 angkatan. Melihat cara manual yang tidak dapat menyajikan laporan secara cepat dan tepat, maka penulis ingin menyiapkan suatu model pengolahan data secara efisien.

Berdasarkan uraian diatas maka dapat diambil kesimpulan bahwa sistem informasi sangat diperlukan dalam dunia pendidikan khususnya yang menyangkut keuangan sekolah. Sebagai contoh dengan memanfaatkan sistem komputerisasi yang diolah dengan menggunakan Bahasa Pemrograman Java serta database MySQL dapat dijadikan sebagai sarana informasi dalam pelaporan data uang sekolah.

\section{PENDEKATAN MASALAH \\ METODE}

Metode pengembangan sistem yang digunakan adalah Siklus Hidup Pengembangan Sistem (System Development Life Cylce) yang terdiri dari beberapa tahap, dimana tahapan yang digunakan adalah :

a. Tahap Analisa Sistem

Mempelajari dan menganalisis sistem yang ada untuk menentukan kebutuhan sistem yang akan dibuat.

b. Tahap Perencanaan Sistem

Merancang sistem informasi berupa perancangan proses, perancangan basis data dan perancangan antarmuka.

c. Tahap Rencana Implementasi Sistem

Penerapan hasil perancangan sistem kedalam bentuk aplikasi sistem informasi dengan menggunakan perangkat lunak tertentu

\section{d. Tahap Perancangan Sistem}

Menguji sistem apakah sistem ini berjalan dengan baik sesuai kebutuhan SMA Negeri 20 Medan.

\section{Sistem}

Menurut Al-Bahra bin Ladjamudin (2005) dalam pemahaman sistem ada dua kelompok pendekatan, yaitu:

1. Pemahaman sistem dengan pendekatan prosedur "Sistem adalah suatu urutan kegiatan yang saling berhubungan, berkumpul bersamasama untuk mencapai tujuan tertentu".

2. Pemahaman sistem dengan pendekatan komponen atau elemen "Sistem adalah kumpulan komponen yang saling berkaitan dan bekerja 
sama untuk mencapai suatu tujuan tertentu".[1]

\section{Informasi}

Sumber informasi adalah data. Data adalah kenyataan yang menggambarkan kejadian-kejadian dan kesatuan nyata. Informasi merupakan data yang telah diproses sedemikian rupa sehingga meningkatkan pengetahuan seseorang yang menggunakannya.

Informasi mempunyai nilai informasi (value Information), ini ditentukan dari dua hal yaitu manfaat dan biaya untuk mendapatkanya. Suatu informasi dikatakan bernilai bila manfaatnya lebih efektif dibandingkan dengan biaya untuk mendapatkanya.[2]

\section{Sistem Informasi}

Sistem Informasi merupakan suatu sistem yang dibuat oleh manusia yang terdiri dari komponen-komponen dalam organisasi untuk mencapai suatu tujuan yaitu menyajikan informasi.

Sistem informasi dapat terdiri dari komponen-komponen yang disebut dengan istilah blok bangunan (building block), yaitu blok masukan (input block), blok model (model block), blok keluaran (output block), blok teknologi(technologi block), blok dasar data (database block), dan blok kendali (control block).

1. Blok masukan

Input mewakili data yang masuk kedalam sistem informasi. Input disini termasuk metode-metode dan media untuk menangkap data yang akan dimasukan, yang dapat berupa dokumen dasar.

2. Blok Model

Blok ini terdiri dari kombinasi prosedur, logika dan model matematik yang akan memanipulasi data input dan data yang tersimpan di dasar data dengan cara yang sudah tertentu untuk menghasilkan keluaran yang diinginkan.

3. Blok Keluaran

Produk dari sistem informasi adalah keluaran yang merupakan informasi yang berkualitas dan dokumentasi yang berguna untuk semua tingkatan manajemen serta semua pemakai sistem

4. Blok Teknologi

Teknologi merupakan alat dalam sistem informasi, teknologi digunakan menerima input, menjalankan model, menyimpan dan mengakses data, menghasilkan dan mengirimkan output, dan membantu pengendalian sistem.

5. Blok Basisdata

Merupakan kumpulan data yang saling berhubungan yang tersimpan di dalam komputer dengan menggunakan software database untuk bisa dipanggil kembali diproses.

6. Blok Kontrol

Pengendalian yang dirancang untuk menanggulangi gangguan terhadap sistem informasi.

\section{Manfaat Sistem Informasi}

Manfaat yang didapat dari sistem informasi dapat diklasifikasikan sebagai berikut:

1. Dapat mengurangi biaya

2. Dapat mengurangi kesalahankesalahan

3. Meningkatkan perencanaan dan pengendalian manajemen

Manfaat sistem informasi dalam bentuk keuntungan berwujud (tangible benefis) dan tidak berwujud (intangible benefis) Keuntungan berwujud antara lain:

1. Pengurangan-pengurangan biaya operasi

2. Pengurangan kesalahan-kesalahan telekomunikasi

Keuntungan tidak berwujud antara lain:

1. Peningkatan pelayanan lebih baik

2. Peningkatan kepuasan kerja personil

3. Peningkatan pengambilan keputusan

\section{HASIL DAN PEMBAHASAN}

\section{Diagram Konteks (Conteks Diagram)}

Diagram Konteks Sistem Informasi

Pengolahan Data uang Komite Sekolah

secara umum dapat dilihat pada 
gambar dibawah ini;

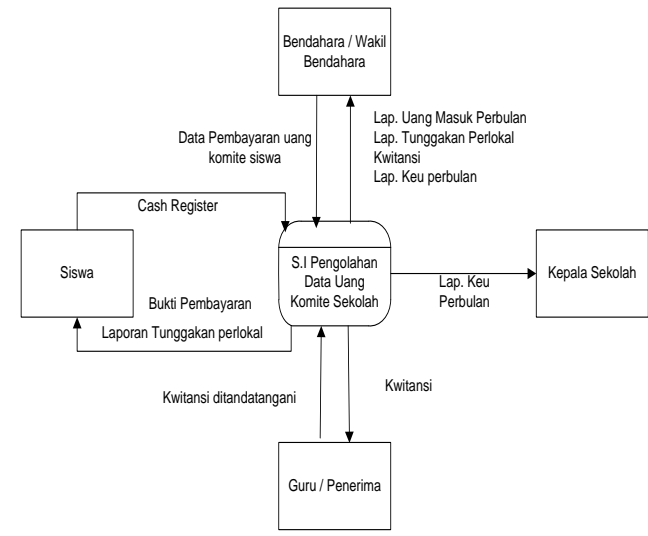

\section{Gambar 1 Context Diagram Sistem Informasi Pengolahan Data Sumbangan Sukarelawan}

\section{Data Flow Diagram (DFD)}

Data Flow Diagram (DFD) menggambarkan sebuah Sistem Informasi yang menitikberatkan pada proses (fokus pada proses). Dengan mengacu kepada Context Diagram, proses yang terjadi diuraikan kedalam bentuk Data Flow Diagram (DFD) level $O$ seperti pada gambar berikut ini;

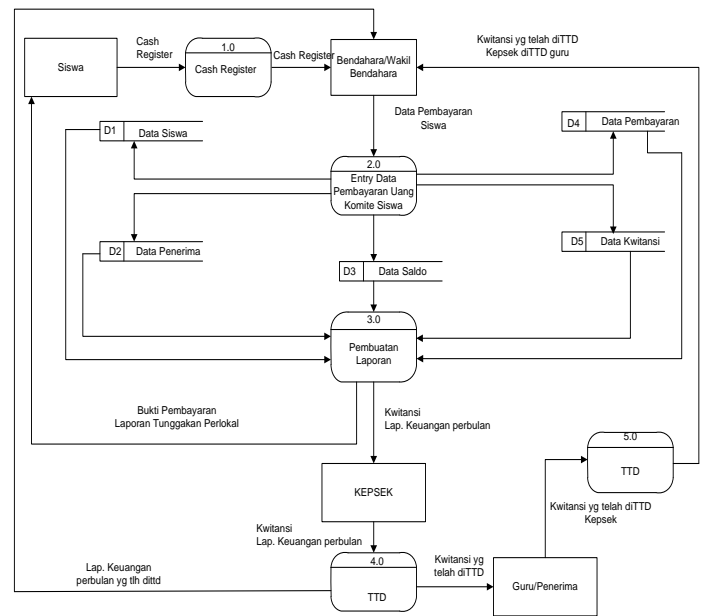

Gambar 2 Data Flow Diagram (DFD)

Level 0 Sistem Informasi Pengolahan Sumbangan

Sukarelawan

\section{Entity Relation Diagram (ERD)}

Pada Entity Relation Diagram (ERD) ini akan Nampak hubungan antara file. File dihubungkan antara satu file dengan file lainnya menggunakan kunci relasi, kunci relasi merupakan kunci utama dari masing-masing file. Relasi (hubungan) dari file ini dapat dilihat pada gambar dibawah ini.

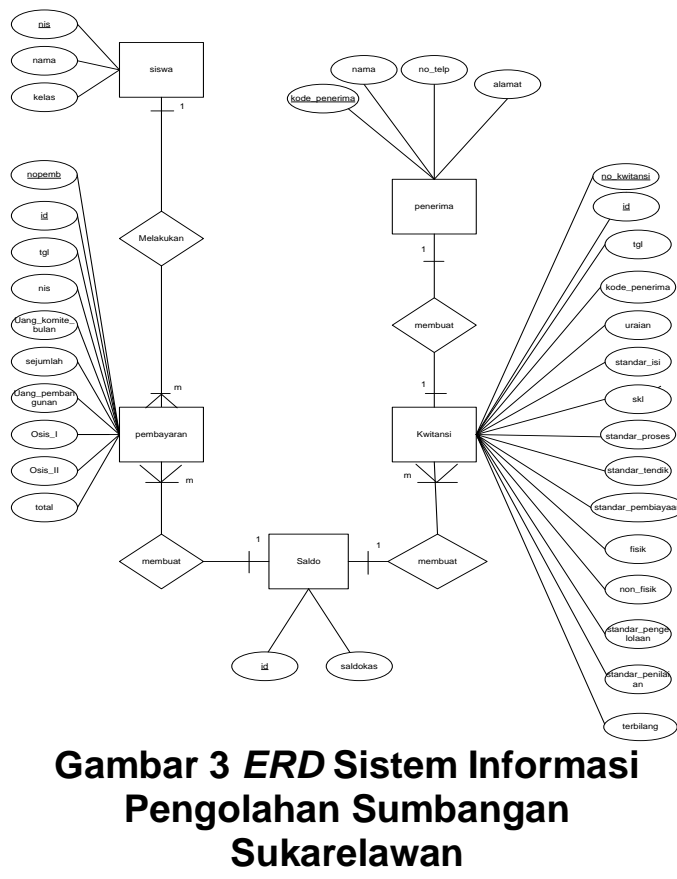

Hasil dari implementasi sistem yaitu mengeluarkan beberapa laporan (output) yang berguna untuk manajemen instansi. Berikut ini dapat dilihat dari menu utama yang merupakan tampilan dari program aplikasi sistem pengolahan data uang sumbangan sukarelawan (Uang SPP Sekolah):

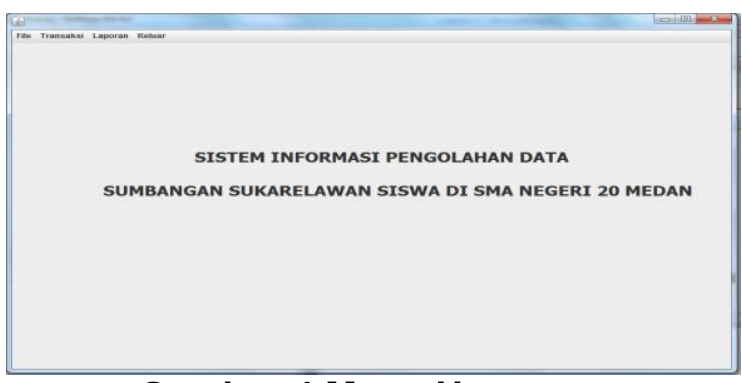

\section{Gambar 4 Menu Utama}

Pada tampilan menu utama ini terdiri dari sub menu file, sub menu transaksi, sub menu laporan, dan sub menu keluar. Dalam sub menu file ada dua modul yaitu modul entry data siswa dan data penerima. Berikut ini tampilan dari modul 


\section{Entry Data Siswa}

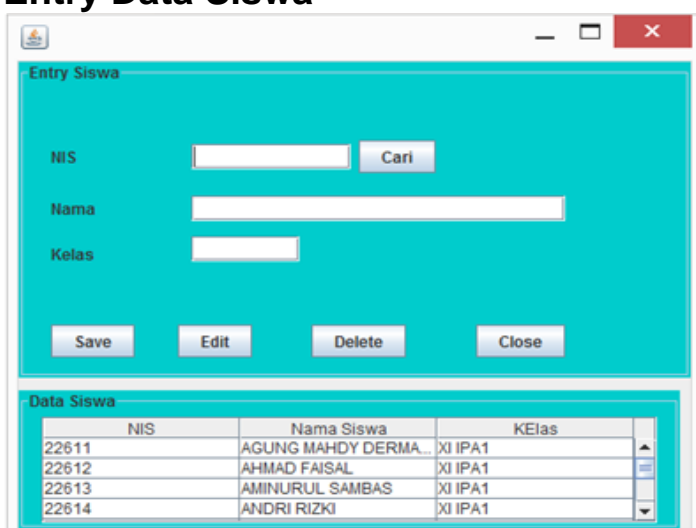

Gambar 5. Form Entry Data Siswa

Selanjutnya tampilan dari modul Entry Data Penerima

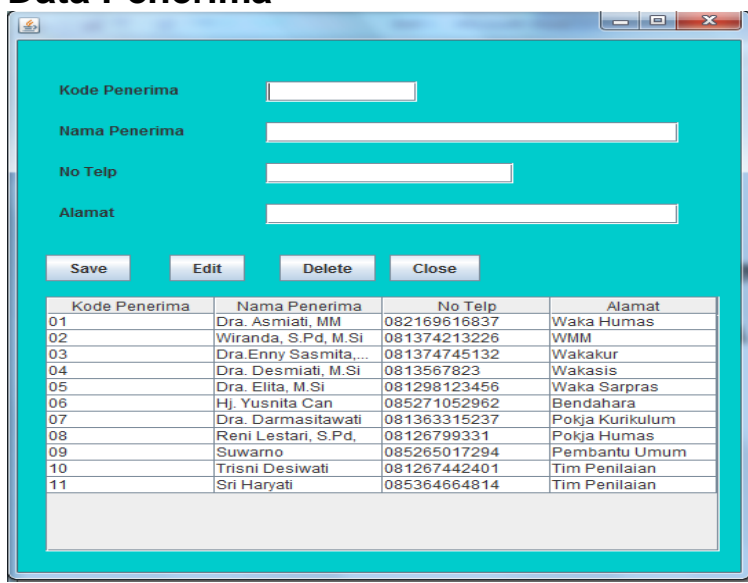

Gambar 6 Entry Data Penerima

\section{Sub Menu Transaksi}

Pada sub menu transaksi, terdapat dua modul, yaitu proses data pembayaran dan data kwitansi, berikut tampilan Transaksi Pembayaran

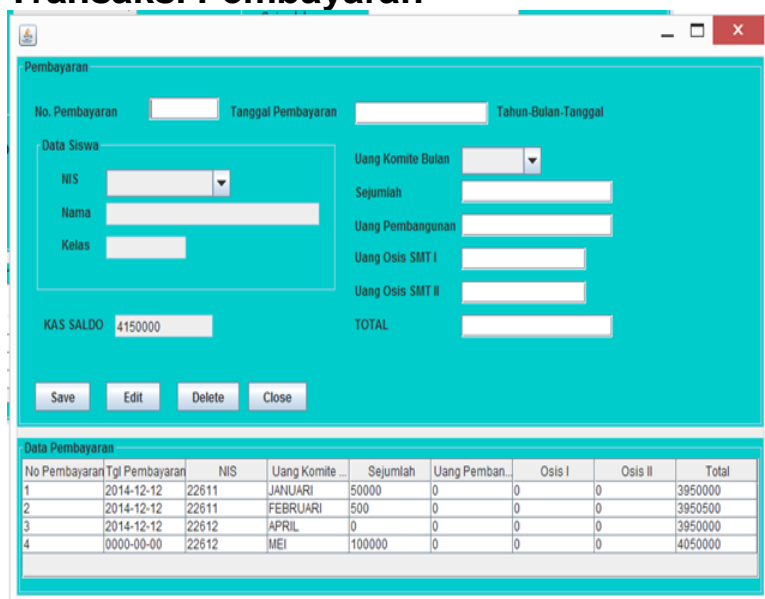

Gambar .7 Transaksi Pembayaran
Selanjutnya tampilan Transaksi

\section{Kwitansi}

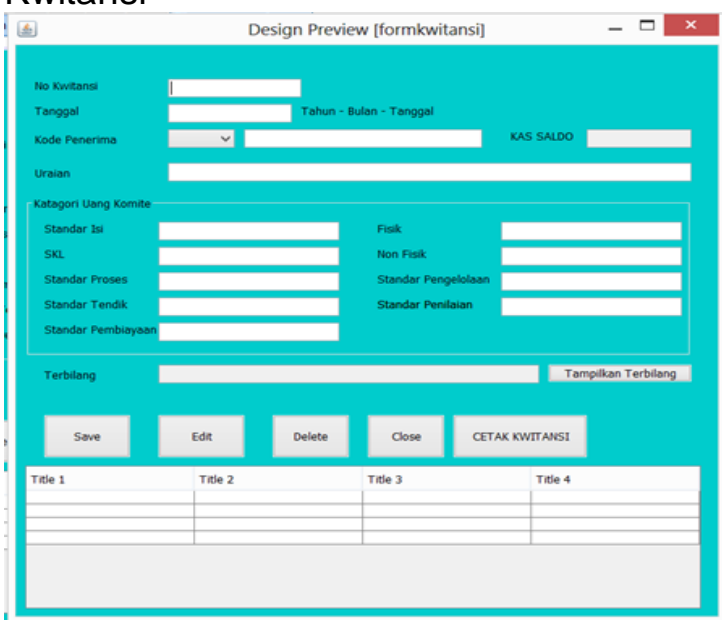

\section{Gambar 8 Transaksi Kwitansi}

\section{Tampilan Laporan}

Terdapat beberapa laporan yang dapat dipertanggung jawabkan pada sistem ini, seperti yang terlihat pada gambar dibawah ini:

1. Bukti Pembayaran

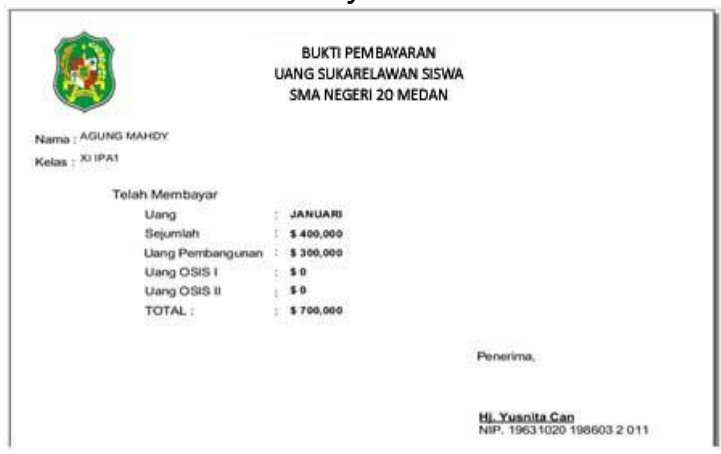

Gambar 9 Bukti Pembayaran

2. Laporan Tunggakan Perlokal

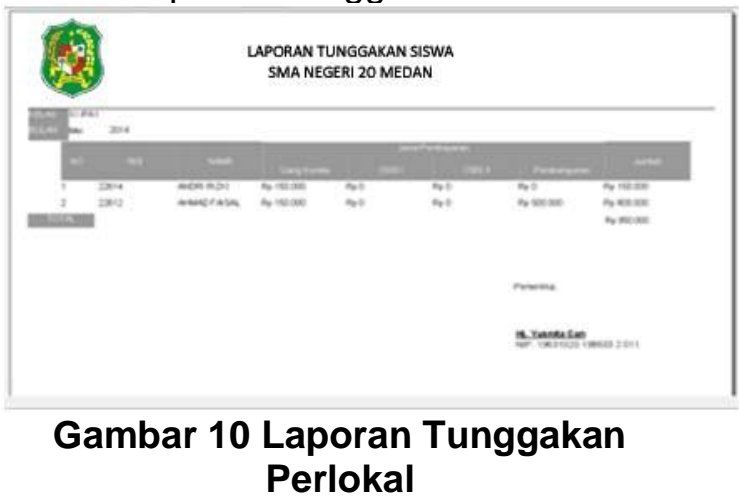


3. Laporan Uang Masuk Perbulan
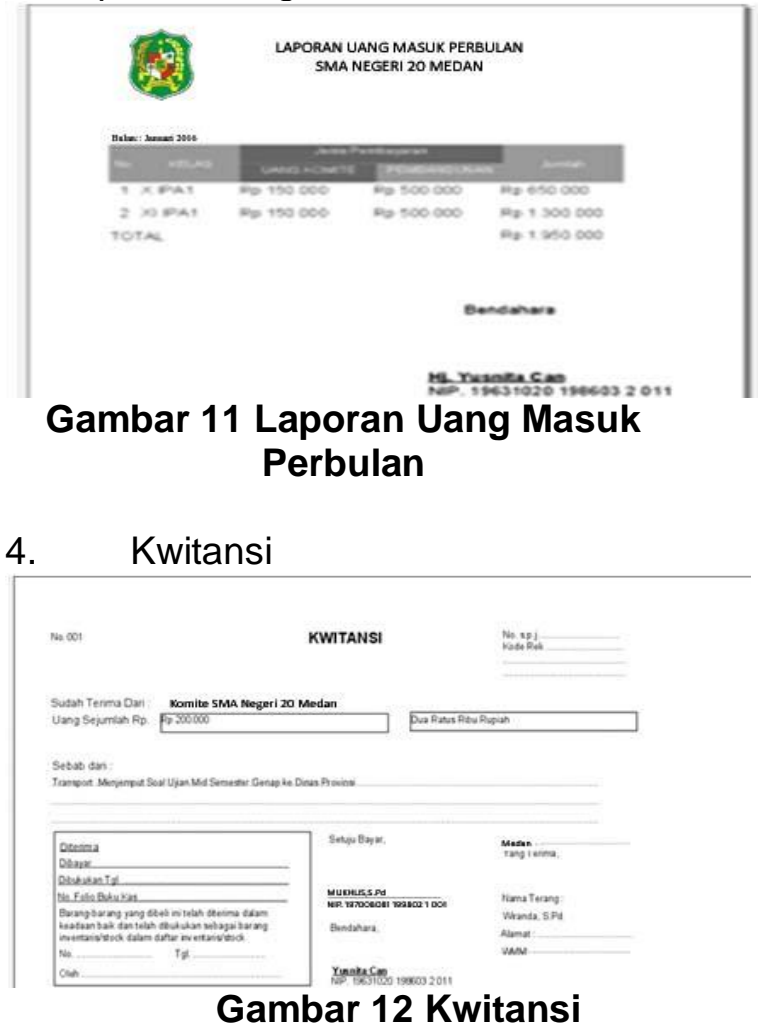

\section{KESIMPULAN}

Setelah melakukan penelitian Sistem Informasi Pengolahan Data Uang Komite Sekolah pada SMA Negeri 2 Padang, maka dapat menarik kesimpulan sebagai berikut:

1. Sistem pengelolaan sumbangan sukarelawan (SPP) pada SMA Negeri 20 Medan sudah memakai computer yaitu dengan excel dalam membuat rekap laporan keuangan sedangkan untuk proses pembayaran sumbangan siswa masih menggunakan cara manual yaitu dengan mencatat kebuku pembayaran uang sumbangan siswa, sehingga dalam membuat laporan sering terjadi kesalahan. Hal ini disebabkan kurang optimalnya penggunaan komputer yang bias mendukung untuk menghasilkan informasi atau laporan yang cepat dan mudah.
2. Sistem informasi yang baru mampu melakukan input datadata yang meliputi: input data siswa, dan data penerima, data saldo serta input transaksi yang meliputi : transaksi pembayaran, dan transaksi kwitansi.

3. Sistem informasi yang baru menghasilkan output seperti: laporan bukti pembayaran, laporan tunggakan perlokal, laporan uang masuk perbulan, kwitansi dan laporan keuangan perbulan.

\section{SARAN}

Berdasarkan rincian sebelumnya, dapat disarankan untuk pengolahan data uang komite pada SMA Negeri 2 Padang sebagai berikut:

1. Dengan adanya program aplikasi pengelolaan sumbangan sukarelawan siswa di SMA Negeri 20 Medan hendaknya dapat meningkatkan efisiensi dan efektifitas kerja.

2. Untuk mengatasi masalahmasalah dalam pengelolaan data sumbangan sukarelawan siswa sebaiknya menggunakan program aplikasi yang telah diusulkan ini di SMA Negeri 20 Medan

\section{DAFTAR PUSTAKA}

[1] Al-Bahra bin Ladjamuddin.B. 2005. Analisis \& desain Sistem Informasi. Graha Ilmu. Jakarta:

[2] Fathansyah. Buku Teks IImu Komputer Basis Data. Remaja Rosdakarya. Bandung

[3] Hartono, Jogiyanto. 2005. Analisis \& Disain, Sistem Informasi: Pendekatan Terstruktur Teori dan Praktek Aplikasi Bisnis". Yogyakarta: Andi 
[4] HeniTriyuliana, Agnes. 2009.

Membuat Aplikasi Database dengan Java 2. Andi dan Wahana Komputer. Yogyakarta

[5] Kadir, Abdul. 2008.Dasar

Perancangan dan Implementasi

Database Relationn. Yogyakarta

[6] Suprapto, Riyanto. 2008.

Pengembangan Aplikasi

Manajemen Database. Gava Media.

Yogyakarta 